\title{
Humanicafé - Encontro nos Setores
}

\author{
Brito, Rosana Aparecida Franchi; Aveiro, Terezinha da Luz Alves; Santos, Jussara \\ da Paixão dos; Costa, Marisa Batista Thomas da \\ Hospital Municipal Maternidade Escola de Vila Nova Cachoeirinha "Dr. Mário de Moraes A. Silva" — \\ teraluz@gmail.com
}

Introdução a Política Nacional de Humanização surge como resposta à baixa qualidade no atendimento ao usuário do SUS, tendo como objetivo a humanização nas relações procurando articular o cuidado técnico científico com o cuidado humano numa relação de respeito mútuo e visando a garantia dos direitos, contribuindo de forma efetiva para melhoria contínua da qualidade na prestação dos serviços. a humanização abrange todas as especialidades e todos os envolvidos no contexto de saúde. Exerce grande importância, considerando que um SUS humanizado pressupõe um processo de pactuação democrática e coletiva. Desde 2001, a Unidade comungava com o conceito de humanização em um sentido amplo visando à construção de uma nova cultura de atendimento a saúde da população pautada no respeito à vida humana e nos direitos constitucionais. Pautado nestes princípios o Grupo de Trabalho de Humanização - GTH da Unidade passou a realizar visitas aos setores, com o objetivo de avançar o SUS, através do olhar dos funcionários sobre o que é real e o que seria o ideal dentro deste Sistema Universal de Saúde. Objetivo Reflexão sobre a realidade institucional e profissional, em busca de alternativas criativas para os desafios encontrados, estabelecendo o diálogo e as informações através de uma rede confiável. Método: São realizados dois encontros por setor com duração de 1 hora e 30 minutos cada um deles. o segundo encontro ocorre em torno de 30 a 40 dias após o primeiro. o método utilizado é o da roda de conversa, um dos dispositivos da PNH. Os coordenadores do GTH utilizam-se de mecanismos como apresentações de filmes, dramatizações, palestras, jograis, cartazes, etc. e procura garantir a participação de todos os elementos do grupo nas rodas de conversa. o grupo deve ao final do encontro identificar uma ação do setor que proporcione melhora de trabalho para o próprio grupo. no retorno, se analisa conjuntamente a ação proposta e o resultado. ao final do encontro é servido um café para todos os elementos do grupo, em um momento de descontração e interação. Resultados: Sensibilização do setor envolvido para a Política Nacional de Humanização, criação de espaço de reflexão e proposição de pelo menos uma ação humanizada no setor após o encontro. Observamos que a maioria dos funcionários não está acostumada à gestão participativa. Quando são convidados a pensar numa estratégia a ser colocada em grupo, eles se sentem incomodados, sentindo que o GTH está dando "função" para eles, que deveria vir pronto. Isto foi devolvido aos funcionários. Conclusões: para se estabelecer a PNH é necessário treino, reflexão, até que participar do processo de trabalho seja um hábito, seja produtivo e amadurecido. Os momentos do Humanicafé proporcionam esse amadurecimento.

Brito, Rosana Aparecida Franchi; Aveiro, Terezinha da Luz Alves; Santos, Jussara da Paixão dos; Costa, Marisa Batista Thomas da. Humanicafé - Encontro nos Setores. In: Anais do Congresso Internacional de Humanidades \& Humanização em Saúde [= Blucher Medical Proceedings, num.2, vol.1]. São Paulo: Editora Blucher, 2014. ISSN 2357-7282

DOI 10.5151/medpro-cihhs-10167 